\title{
Hydroformylation with Cobalt Carbonyl and Cobalt Carbonyl-Tributylphosphine Catalysts
}

\author{
M. van Boven, N. H. Alemdaroglu, ${ }^{1}$ and J. M. L. Penninger ${ }^{* 2}$ \\ Laboratory for Chemical Technology, Twente University of Technology, Enschede, The Netherlands
}

\begin{abstract}
By in situ ir spectroscopic techniques it was found that the cobalt carbonyl catalyst in hexane, after preforming at conditions of hydroformylation (temperatures of 101 and $124^{\circ} \mathrm{C}, P_{\mathrm{CO}}=11$ and $30 \mathrm{bars}, P_{\mathrm{H}_{2}}=20$ and 49 bars, cobalt concentration $=2.0$ and $4.2 \mathrm{mmol} / \mathrm{l}$.) consisted of more than $80 \% \mathrm{HCo}(\mathrm{CO})_{4}$, the rest being $\mathrm{CO}_{2}(\mathrm{CO})_{8}$. Injection of octene-1, in order to start the hydroformylation, caused $\mathrm{HCO}(\mathrm{CO})_{4}$ to decrease (although not to zero concentration) in favor of an increasing $\mathrm{Co}_{2}(\mathrm{CO})_{8}$ concentration. This reverted as the conversion of octene-1 increased. As intermediate complexes, only acyl cobalt carbonyl species were detected in very low concentrations. A catalyst composed of cobalt carbonyl and tributylphosphine in a phosphorus-to-cobalt ratio of 5 , of a considerable amount of catalytically inactive $\mathrm{CO}_{2}(\mathrm{CO})_{7} \mathrm{PBu}_{3}$, while of all hydridocobalt carbonyls present only a minor part was liganded by $\mathrm{PBu}_{3}$ at the previously mentioned reaction conditions. Accordingly, in the hydroformylation of octene-1, the catalyst decreased only the octene conversion rate and left the yield of unbranched products unaffected.
\end{abstract}

\section{Introduction}

Experimental evidence has been obtained for many of the intermediate reactions proposed to occur in the hydroformylation of olefins (Heck and Breslow, 1960, 1961; Orchin and Rupilius, 1972). Although the extensive work done has provided an experimental foundation, one must realize that most of the studies were done at ambient or subambient conditions while the technical oxo reaction proceeds at substantially higher temperatures and pressures. So far, no complete picture of the reaction system derived from in situ analyses at technical oxo conditions has been obtained.

An identical situation is found around the cobalt carbonyl catalyst modified with organophosphorus compounds. Many investigations report the effects on the oxo reaction of organophosphorus or -phosphite components added to the cobalt carbonyl catalyst (Paulik, 1972), but experimental data on ligand exchange reactions under the conditions of technical hydroformylations is lacking. Several tentative interpretations have been put forward, but the real composition of the different catalyst systems is still not known. Also the influence of olefins on a catalyst system under technical oxo conditions is merely speculative.

The development of high-temperature/pressure ir spectroscopic cells in recent years (Oltay et al., 1973, which gives further references) has provided a proper analytical tool which may solve many of the aforementioned questions. Whyman (1974) recently published the first observations ever done by in situ ir spectroscopy on the cobalt carbonyl catalyst. The investigation reported in the present paper was undertaken as an introductory study of the actual catalyst composition at the prevailing hydroformylation conditions, especially in relation to the catalyst-olefin interaction.

\footnotetext{
${ }^{1}$ Akzo Zout Chemie Central Research, Hengelo, The Netherlands.

${ }^{2}$ Address correspondence to this author at Akzo Chemie B.V., P.O. Box 247, Amersfoort, The Netherlands.
}

\section{Experimental Section}

The reactions were carried out in a 1-1. AISI 316 autoclave equipped with an impeller type stirrer. The bomb was connected with a system to supply the catalyst solution and/or olefins under elevated temperature and pressure. Also connected was a synthesis gas tank to compensate the pressure in the autoclave for consumed gas.

After charging the catalyst, dissolved in heptane, ample time was given to preform the catalyst at the reaction conditions before the oxo reaction was started by injection of octene-1. Samples were taken through a capillary line, without releasing the pressure, into the high-pressure ir cell. This was of a type described previously (Oltay et al., 1973). The temperature of the liquid in the autoclave, the transfer line, and ir cell were controlled carefully at the same value within a range of $1^{\circ} \mathrm{C}$.

Ir spectra of the confined samples were taken with a Perkin-Elmer Type 357 ir spectrometer.

After transfer from the high-pressure cell the same samples were also analyzed at ambient conditions: by ir for the catalyst system and by GLC for hydrocarbon compositions (Carbowax 1000 on chromosorb W 60-80 mesh, $3.5 \mathrm{~m} \times 1 / 4$ in. $\mathrm{H}_{2}$, hot wire detector, temperature program $75-150^{\circ} \mathrm{C}$ with $10^{\circ} / \mathrm{min}$ ).

The concentration of the different carbonyl species was calculated from absorptivity measurements at frequencies which are characteristic for each species, namely $\mathrm{Co}_{2}(\mathrm{CO})_{8}$, $2070 \mathrm{~cm}^{-1} ; \mathrm{HCo}(\mathrm{CO})_{4}, 2055 \mathrm{~cm}^{-1} ; \mathrm{Co}_{2}(\mathrm{CO})_{7} \mathrm{PBu}_{3}, 1992$ $\mathrm{cm}^{-1}$; and $\mathrm{HCo}(\mathrm{CO})_{3} \mathrm{PBu}_{3}, 1970 \mathrm{~cm}^{-1}$. They are so chosen, that overlap by other absorptions is zero. This is the reason why for $\mathrm{Co}_{2}(\mathrm{CO})_{8}$ the 2070 peak was chosen rather than absorptions at lower frequencies, although they are stronger. For $\mathrm{HCo}(\mathrm{CO})_{4}, 2055 \mathrm{~cm}^{-1}$ was chosen because the much stronger absorption at $2032 \mathrm{~cm}^{-1}$ interferes with a weak absorption peak of $\mathrm{Co}_{2}(\mathrm{CO})_{8}$ at $2031 \mathrm{~cm}^{-1}$ and with the absorption of $\mathrm{C}_{8} \mathrm{H}_{16} \mathrm{Co}(\mathrm{CO})_{4}$ at $2031 \mathrm{~cm}^{-1}$ (see Table I). Further, the intensity of the transmitted radiation was $10 \%$ or less at $2032 \mathrm{~cm}^{-1}$ which made the concentration determination too inaccurate.

The calibration of absorptivity vs. concentration was obtained from test mixtures prepared at reaction conditions 


\begin{tabular}{llll}
\hline \multicolumn{1}{c}{ Compound } & \multicolumn{1}{c}{ Vibration frequencies, $\mathrm{cm}^{-1} a$} & Ref \\
\hline $\mathrm{Co}_{2}(\mathrm{CO})_{8}$ (bridged) & $2112 \mathrm{vw}, 2071 \mathrm{~s}, 2059 \mathrm{vw}, 2044 / 42 \mathrm{vs}, 2031 \mathrm{vw}, 1866 \mathrm{w}, 1856 \mathrm{~m}$. & $c$ \\
$\mathrm{Co}_{2}(\mathrm{CO})_{8}$ (nonbridged) & $2107 \mathrm{sh}, 2069 \mathrm{~s}, 2044 / 42 \mathrm{vs}, 2031 \mathrm{vw}, 2023 \mathrm{~s}, 1991 \mathrm{w}$ & $c$ \\
$\mathrm{HCo}(\mathrm{CO})_{4}$ & $2118(0.62), 2055(5.4), 2032(10), 1955(0.34)$ & $b, f$ \\
$n-\mathrm{C}_{8} \mathrm{H}_{17} \mathrm{COCO}(\mathrm{CO})_{4}$ & $2103(2.9), 2044(5.8), 2022(9.8), 2003(10)$ & $f$ \\
$n-\mathrm{C}_{8} \mathrm{H}_{17} \mathrm{Co}(\mathrm{CO})_{4}$ & $2014 \mathrm{vs}, 2031 \mathrm{~m}, 2100 \mathrm{vw}$ & $f$ \\
$\mathrm{Co}_{2}(\mathrm{CO})_{7} \mathrm{PBu}_{3}$ & $2078 \mathrm{~m}, 2022 \mathrm{~m}, 2005 \mathrm{sh}, 1992 \mathrm{vs}, 1955 \mathrm{~m}$ & $d$ \\
$\mathrm{Co}_{2}(\mathrm{CO})_{6}\left(\mathrm{PBu}_{3}\right)_{2}$ & $1972 \mathrm{~m} \mathrm{sh}, 1953 \mathrm{vs}, 1927 \mathrm{wsh}$ & $e$ \\
$\mathrm{HCO}_{2}(\mathrm{CO})_{3} \mathrm{PBu}_{3}$ & $2049 \mathrm{mw}, 1970 \mathrm{vs}, 1935 \mathrm{w}$ & $e$
\end{tabular}

${ }^{a}$ Notations behind the frequency data give the ratio of the respective $\ln \left(I_{0} / I\right)$ values. ${ }^{b} \ln \left(I_{0} / I\right)$ values derived from own measurements. ${ }^{c}$ Bor (1963). ${ }^{d}$ Ungvary (1972). ${ }^{e}$ Whyman (1972); Piacenta et al. (1967). ${ }^{f}$ Markó et al. (1963).

by a systematic step procedure. Starting from a $\mathrm{Co}_{2}(\mathrm{CO})_{8}$ solution of known concentration, $\mathrm{PBu}_{3}$ was added. From the decrease in $\mathrm{Co}_{2}(\mathrm{CO})_{8}$ the amount of $\mathrm{Co}_{2}(\mathrm{CO})_{7} \mathrm{PBu}_{3}$ was calculated and related to the characteristic absorptivity. In a similar way $\mathrm{HCo}(\mathrm{CO})_{4}$ was calibrated from a $\mathrm{Co}_{2}(\mathrm{CO})_{8}$ solution and subsequent addition of hydrogen. Calibration of $\mathrm{HCo}(\mathrm{CO})_{3} \mathrm{PBu}_{3}$ was accomplished by addition of hydrogen to a $\mathrm{Co}_{2}(\mathrm{CO})_{7} \mathrm{PBu}_{3}$ solution.

The data obtained were correlated according to Beer's law

$$
\ln I_{0} / I=\epsilon b c
$$

where $I / I_{0}$ is the relative intensity of transmitted radiation at the characteristic frequency, $\epsilon$ is the absorptivity coëfficient, $b$ is the cell path length, and $c$ is the concentration of the component. The following values of $\epsilon$, relative to that of $\mathrm{Co}_{2}(\mathrm{CO})_{8}$, were found at $100^{\circ} \mathrm{C}: \epsilon\left(\mathrm{Co}_{2}(\mathrm{CO})_{8}\right)=1, \epsilon(\mathrm{HCo}-$ $\left.(\mathrm{CO})_{4}\right)=0.56, \epsilon\left(\mathrm{Co}_{2}(\mathrm{CO})_{7} \mathrm{PBu}_{3}\right)=1.84$, and $\epsilon\left(\mathrm{HCo}(\mathrm{CO})_{3} \mathrm{P}\right.$ $\left.\mathrm{Bu}_{3}\right)=0.36$.

Reactants were: $n$-heptane as solvent (Baker), purity $99 \%$, bp $97.8-98.3^{\circ} \mathrm{C}$; octene-1 (Baker) purity $99 \%$, bp $121-122^{\circ} \mathrm{C}$; and tributylphosphine (Baker) pur. 98\%. All liquids were stored over activated mol sieves. Dicobaltoctacarbonyl was prepared according to King (1965) and Szabo et al. (1961), double crystallized from dichloromethane (Merck, pur. 99\%) and dried/stored under carbon monoxide, purity of carbonyl $97-98 \%$ according to cobalt content (Schwartzenbach and Flaschka, 1969). Carbon monoxide and hydrogen (Hoek-Rotterdam) were used without further pretreatment.

\section{Results}

1. Hydroformylation with the Cobalt Carbonyl Catalyst. From preliminary experiments it was found that at a temperature of approximately $150^{\circ} \mathrm{C}$, which is common in technical oxo processes, the reaction was too fast to distinguish different stages of its progress by ir scanning; a lower temperature in the range of $100-125^{\circ} \mathrm{C}$ was found to be more appropriate. A set of ir spectra obtained with conversion of octene at $101^{\circ} \mathrm{C}$ is shown in Figure 1. The catalyst, after a preforming stage of approximately $1 \mathrm{hr}$, consists of a mixture of $\mathrm{HCo}(\mathrm{CO})_{4}$ and $\mathrm{Co}_{2}(\mathrm{CO})_{8}$, in which the former dominates (Figure $1 \mathrm{~A}$ ). The thermodynamic equilibrium of the reaction $\mathrm{Co}_{2}(\mathrm{CO})_{8}+\mathrm{H}_{2}=2 \mathrm{HCo}(\mathrm{CO})_{4}$ was not completely reached after $1 \mathrm{hr}$ of preforming.

According to the equilibrium data of Ungvary (1972) 91 mol \% of all cobalt present should be in the form of $\mathrm{HCo}(\mathrm{CO})_{4}$, but Figure $1 \mathrm{~A}$ indicates only $84 \%$. Injection of octene-1 into the catalyst solution to start the hydroformylation causes only minor changes in the carbonyl vibration region (Figure $1 \mathrm{~B}, \mathrm{C}$, and D). However, it can be seen that all peaks characteristic for $\mathrm{HCo}(\mathrm{CO})_{4}$ are decreased and these of $\mathrm{Co}_{2}(\mathrm{CO})_{8}$ increased. Using the relative intensity data $\left(\ln I_{0} / I\right)$ of the compound characteristic frequencies, viz. $2055 \mathrm{~cm}^{-1}$ for $\mathrm{HCo}(\mathrm{CO})_{4}$ and $2070 \mathrm{~cm}^{-1}$ for $\mathrm{Co}_{2}(\mathrm{CO})_{8}$ as a reference (Figure $1 \mathrm{~B}$ ), all other absorptions of these compounds were calculated according to the following ratio of the relative intensities: $\mathrm{HCo}(\mathrm{CO})_{4}: 2118 \mathrm{~cm}^{-1}-0.62$, $2055 \mathrm{~cm}^{-1}-5.4,2032 \mathrm{~cm}^{-1}-10,1995 \mathrm{~cm}^{-1}-0.34$. $\mathrm{Co}_{2}(\mathrm{CO})_{8}: 2071 \mathrm{~cm}^{-1}-7.7,2044 / 42 \mathrm{~cm}^{-1}-10,2023 \mathrm{~cm}^{-1}$ $-7.4,1857 \mathrm{~cm}^{-1}-2.4$.

The resulting peak absorptivities are drawn in Figure 2, which also displays the spectral pattern of Figure 1B. It can be seen that the experimental spectrum results only from a mixture of $\mathrm{HCo}(\mathrm{CO})_{4}$ and $\mathrm{Co}_{2}(\mathrm{CO})_{8}$ and essentially no other compounds.

From Figure 1A, making use of the known relative values of $\epsilon_{1}$ and $\epsilon_{2}$, the absorptivities at $2070 \mathrm{~cm}^{-1}$ and $2055 \mathrm{~cm}^{-1}$ were correlated with the absolute concentration of $\mathrm{Co}_{2}(\mathrm{CO})_{8}$ and $\mathrm{HCo}(\mathrm{CO})_{4}$, respectively, which were calculated from the decrease of the $\mathrm{Co}_{2}(\mathrm{CO})_{8}$ concentration present prior to preforming. Found correlations were applied in calculating the concentrations of $\mathrm{HCo}(\mathrm{CO})_{4}$ and $\mathrm{Co}_{2}(\mathrm{CO})_{8}$ from Figures $1 \mathrm{~B}$ to $1 \mathrm{D}$. A plot is given in Figure 3a. The amount of cobalt present as said species was, within a deviation of $3 \%$ throughout the whole range of reaction times, equal to the total amount of cobalt initially added to the reaction system. This implies that only a very minor amount of cobalt can be present in the form of other cobalt carbonyl species, such as alkyl- and/or acyl cobalt tetracarbonyl. Assuming this would correspond to $3 \%$ of the total cobalt added, then the ratio of alkyl- and/or acyl cobalt tetracarbonyl-to-olefin approximates $2 \times 10^{-4}$ for an olefin concentration of $0.304 \mathrm{M}$.

The spectra $1 \mathrm{~B}$ and $1 \mathrm{C}$ show an extra peak which appears as a weak shoulder at a frequency of slightly above $2000 \mathrm{~cm}^{-1}$ (marked * in Figure 1). This indicates very small concentrations of the acyl cobalt tetracarbonyl complex of octene-1 which has its strongest absorption at $2003 \mathrm{~cm}^{-1}$ (Table 1). All other vibrations of this complex are much less intensive and fall in the range of the stronger $\mathrm{HCo}(\mathrm{CO})_{4} /$ $\mathrm{Co}_{2}(\mathrm{CO})_{8}$ vibrations, so that they are not resolved. The acyl complex was much more clearly seen by recording the samples at ambient conditions. Under exclusion of air the acyl complex solution was stable enough to produce repeatable spectra without losing intensity. A characteristic spectrum is shown in Figure 4; the typical acyl complex peaks at 2003 and $2103 \mathrm{~cm}^{-1}$ are clearly resolved from the stronger $\mathrm{Co}_{2}(\mathrm{CO})_{8}$ peaks.

An accurate determination of the concentration of the acyl complex at in situ hydroformylation conditions is difficult to accomplish because of the low concentration and thus poor resolution of said complex. Nevertheless the trend with the reaction time in the $\ln \left(I_{0} / I\right)$ values of the $2103-\mathrm{cm}^{-1}$ peak measured from ambient spectra may give an impression of the trend of the actual concentration (Figure 3a). The alkyl cobalt tetracarbonyl complex was not present; it should be responsible for a vibration at approxi- 

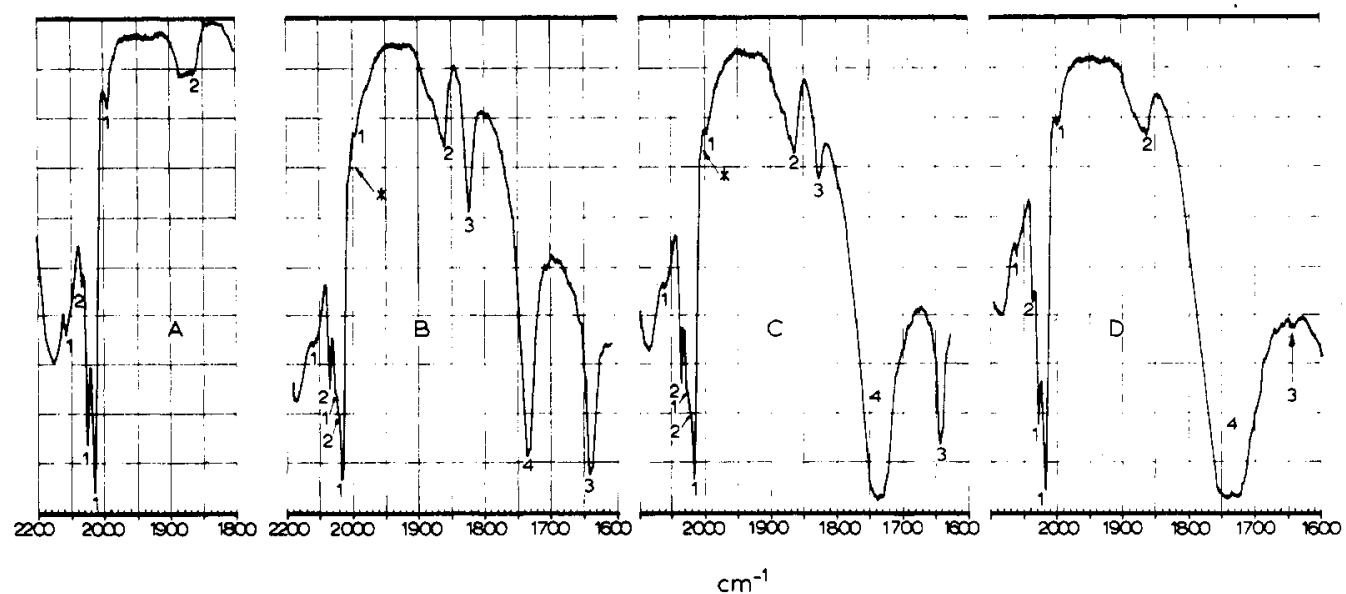

Figure 1. In situ ir spectra taken at different stages of the hydroformylation of octene-1 with cobalt carbonyl catalyst $101^{\circ} \mathrm{C}, P_{\mathrm{CO}}=11$ bars, $P_{\mathrm{H}_{2}}=49$ bars, [cobalt] $=2.14 \mathrm{mmol} / 1$., initial [octene-1] $=0.304 \mathrm{~mol} / 1$. A, preformed catalyst; $\mathrm{B}, 4 \mathrm{~min}$ after octene injection; C, 37 min after octene injection; $\mathrm{D}, 165$ min after octene injection; $1, \mathrm{HCo}(\mathrm{CO})_{4} ; 2, \mathrm{Co}_{2}(\mathrm{CO})_{8} ; 3$, octene-1; 4, aldehydes; *, acyl cobalt carbonyl.

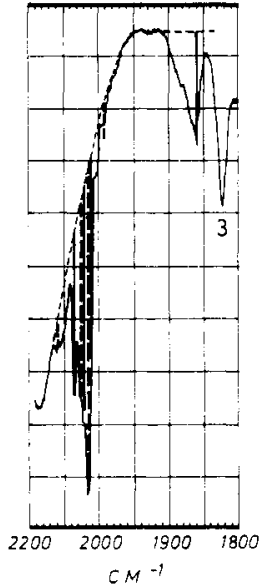

Figure 2. Individual absorptions of $\mathrm{HCo}(\mathrm{CO})_{4}(\ldots)$ and $\mathrm{Co}_{2}(\mathrm{CO})_{8}$ $(-)$ compared with the spectral pattern of Figure 1B; 3 , octene-1.

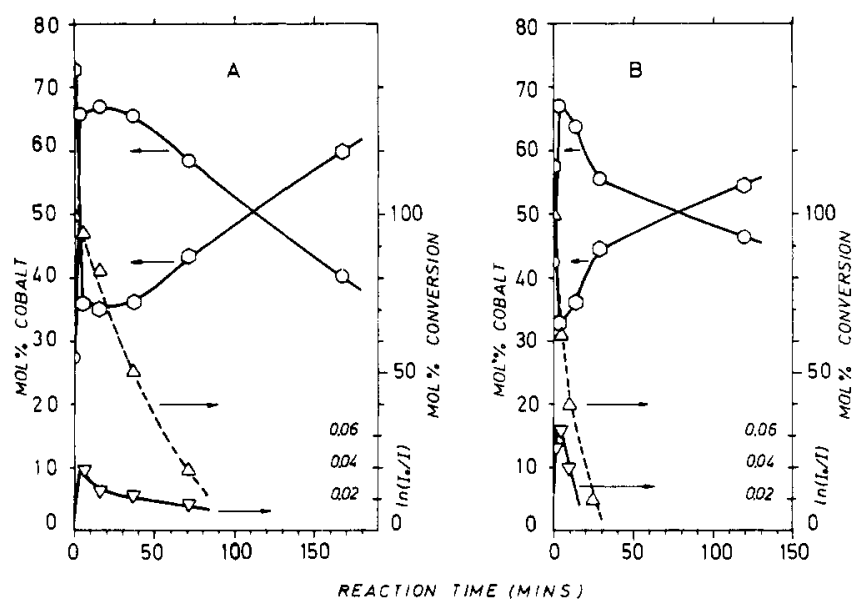

Figure 3. Cobalt carbonyl composition and octene-1 conversion as a function of the reaction time: $\mathrm{O}, \mathrm{HCo}(\mathrm{CO})_{4} ; \mathrm{O}, \mathrm{Co}_{2}(\mathrm{CO})_{8} ; \Delta$, octene-1; $\nabla$, acyl compound. A, $101^{\circ} \mathrm{C}, P_{\mathrm{CO}}=11$ bars, $P_{\mathrm{H}_{2}}=49$ bars, [cobalt] $=2.14 \mathrm{mmol} / \mathrm{l}$; yield of unbranched aldehydes formed: $76 \%, \mathrm{~B}, 124^{\circ} \mathrm{C}, P_{\mathrm{CO}}=20$ bars, $P_{\mathrm{H}_{2}}=60$ bars, $[$ cobalt $]=4.28$ $\mathrm{mmol} / \mathrm{l}$; yield of unbranched aldehydes formed: $82 \%$

mately $2014 \mathrm{~cm}^{-1}$, where the complex has its strongest and most characteristic absorption (Table I).

The experiments were repeated at a temperature of $124^{\circ} \mathrm{C}$ (further reaction conditions are listed under Figure $3 b)$. An increase was observed in both the octene conver-

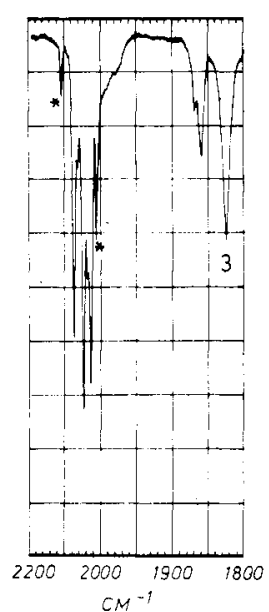

Figure 4. Ir spectrum recorded at ambient conditions of same sample which produced the in situ spectral pattern as given in Figure 1B: *, acyl cobalt carbonyl; 3 , octene-1; others, $\mathrm{Co}_{2}(\mathrm{CO})_{8}$.

sion rate ( $90 \%$ conversion in $30 \mathrm{~min}$ ) and the yield of unbranched products ( $82 \%)$. The trend in the concentration of $\mathrm{HCo}(\mathrm{CO})_{4}$ and $\mathrm{Co}_{2}(\mathrm{CO})_{8}$ and the ratio of the said species with octene conversion was very similar to that observed in the $101^{\circ} \mathrm{C}$ experiment. With a deviation of a few percent all of the cobalt in the system was found present as $\mathrm{HCo}(\mathrm{CO})_{4}$ and $\mathrm{Co}_{2}(\mathrm{CO})_{8}$. A weak shoulder at approximately 2000 $\mathrm{cm}^{-1}$ indicated a low concentration of the acyl complex.

In summarizing the preceding observations one may conclude that under the prevailing hydroformylation conditions the dominant carbonyl species are $\mathrm{HCo}(\mathrm{CO})_{4}$ and $\mathrm{Co}_{2}(\mathrm{CO})_{8}$. Their concentrations change almost stepwise by the injection of octene-1 but revert gradually as conversion proceeds. The acyl cobalt tetracarbonyl complex of octene1 is the only detectable intermediate; its concentration rises sharply after olefin injection and then drops gradually with proceeding olefin conversion.

\section{Discussion}

The mechanism of the hydroformylation is usually described by the following set of reactions.

$$
\begin{gathered}
\mathrm{Co}_{2}(\mathrm{CO})_{8}+\mathrm{H}_{2} \leftrightharpoons 2 \mathrm{HCo}(\mathrm{CO})_{4} \\
\mathrm{HCo}(\mathrm{CO})_{4}+\text { octene }-1 \leftrightharpoons \mathrm{RCo}(\mathrm{CO})_{4} \\
\mathrm{RCo}(\mathrm{CO})_{4} \leftrightharpoons \mathrm{RCO}-\mathrm{Co}(\mathrm{CO})_{3} \underset{+\mathrm{CO}}{\rightleftharpoons} \mathrm{RCOCo}(\mathrm{CO})_{4}
\end{gathered}
$$




$$
\begin{aligned}
& \mathrm{RCOCo}(\mathrm{CO})_{4}+\mathrm{H}_{2} \longrightarrow \mathrm{RC}_{\mathrm{H}}^{\mathrm{O}}+\mathrm{HCo}(\mathrm{CO})_{4} \\
& \text { and/or } \\
& \mathrm{RCOCo}(\mathrm{CO})_{4}+\mathrm{HCo}(\mathrm{CO})_{4} \rightarrow \mathrm{RC}_{\mathrm{H}}^{\mathrm{O}}+\mathrm{Co}_{2}(\mathrm{CO})_{8}
\end{aligned}
$$

With the data reported in the preceding section the reactions, which are slow under the prevailing conditions, can be tentatively indicated. Of all the species in the scheme, besides reactants and products, only $\mathrm{HCo}(\mathrm{CO})_{4}, \mathrm{Co}_{2}(\mathrm{CO})_{8}$, and $\mathrm{RCOCo}(\mathrm{CO})_{4}$ were found to be present in detectable concentrations. This indicates that reaction 3 is displaced completely to the right-hand side. The sharp decrease of the $\mathrm{HCo}(\mathrm{CO})_{4}$ concentration, immediately after the injection of octene-1 to an approximate steady-state level far above zero concentration, and the simultaneous increase of $\mathrm{RCOCo}(\mathrm{CO})_{4}$ indicate the equilibrium relation between $\mathrm{HCo}(\mathrm{CO})_{4} /$ octene- 1 and $\mathrm{RCOCo}(\mathrm{CO})_{4}$ via reactions 2 and 3 so that the intermediate alkyl complexes have no detectable concentrations.

Assuming reaction 1 to be much faster than any other reaction of the sequence, the equilibrium between $\mathrm{Co}_{2}(\mathrm{CO})_{8}$ and $\mathrm{HCo}(\mathrm{CO})_{4}$ would not be disturbed much and their ratio would remain equal before and after the addition of the olefin. This is in conflict with the reported data.

Having experienced that the establishment of the equilibrium between $\mathrm{Co}_{2}(\mathrm{CO})_{8}$ and $\mathrm{HCo}(\mathrm{CO})_{4}$ requires several hours at $100^{\circ} \mathrm{C}$ it seems more appropriate to assume that reaction 1 is slow, at least slower than the consecutive reaction 2. In this case addition of octene-1 will consume a part of $\mathrm{HCo}(\mathrm{CO})_{4}$ by forming the acyl complex with a rate faster than it can be up-graded by reaction 1 and results in a decrease of the $\mathrm{HCo}(\mathrm{CO})_{4}$ concentration. The concentration of $\mathrm{Co}_{2}(\mathrm{CO})_{8}$ is then profoundly affected by the mechanism of break-up of the acylcomplex (reaction 4). If the latter reaction proceeds by a reaction with $\mathrm{H}_{2}$ (reaction 4a), $\mathrm{HCO}(\mathrm{CO})_{4}$ is formed directly and will contribute immediately to the equilibrium concentration of the acyl complex via the fast reaction 2.

Actually, $\mathrm{Co}_{2}(\mathrm{CO})_{8}$ does not play any role in this sequence after the initial formation of $\mathrm{HCo}(\mathrm{CO})_{4}$ since each mole of the latter consumed produces one mole directly in return. The concentration of $\mathrm{Co}_{2}(\mathrm{CO})_{4}$ would thus decrease gradually after injection of octene-1 until the equilibrium relation with the steady-state $\mathrm{HCo}(\mathrm{CO})_{4}$ concentration was restored. This is not observed in the experiments. Furthermore, the "gap" in $\mathrm{HCo}(\mathrm{CO})_{4}$ initially created would run parallel to a corresponding increase of the intermediate complexes, such as the acyl complex. Although the latter was indeed detected, its concentration is far too low to account for the said effect. It is therefore more likely that the acyl complex reacts with $\mathrm{HCo}(\mathrm{CO})_{4}$ (reaction 4 b) to form the aldehyde and $\mathrm{Co}_{2}(\mathrm{CO})_{8}$. When this proceeds with a rate faster than the rate of reaction 1 , the $\mathrm{Co}_{2}(\mathrm{CO})_{8}$ thus formed builds up and retains a good deal of $\mathrm{HCo}(\mathrm{CO})_{4}$ initially present before the injection of octene-1. This hypothesis closely approximates the experimental results, which show that the decrease in the $\mathrm{HCo}(\mathrm{CO})_{4}$ concentration corresponds to the increase of $\mathrm{Co}_{2}(\mathrm{CO})_{8}$. One may conclude that the hydroformylation of octene- 1 in the temperature range of 100 to $124^{\circ} \mathrm{C}$ and under the prevailing conditions of partial pressures and cobalt concentrations is best described by the following simplified mechanism.

$$
\begin{gathered}
\mathrm{Co}_{2}(\mathrm{CO})_{8}+\mathrm{H}_{2} \longrightarrow 2 \mathrm{HCo}(\mathrm{CO})_{4} \\
\mathrm{HCo}(\mathrm{CO})_{4}+\text { octene }-1 \leftrightharpoons \mathrm{RCOCo}(\mathrm{CO})_{4} \\
\mathrm{RCOCo}(\mathrm{CO})_{4}+\mathrm{HCo}(\mathrm{CO})_{4} \longrightarrow \mathrm{RC}_{\mathrm{H}}^{=\mathrm{O}}+\mathrm{CO}_{2}(\mathrm{CO})_{8}
\end{gathered}
$$

The findings of the present work are different from the earlier work of Markó (1963) and Orchin (1956). Both investigators determined the carbonyl composition of the reaction mixture by ir spectroscopy and found a spectrum dominated in the carbonyl region by $\mathrm{Co}_{2}(\mathrm{CO})_{8}$ and the acyl complex. No free $\mathrm{HCo}(\mathrm{CO})_{4}$ was detected as long as olefin was present.

In evaluating the latter results, the following must be kept in mind. First, all ir spectral analysis were done on samples collected at normal pressure. Although the sample containers were cooled to temperatures far below $0^{\circ} \mathrm{C}$, in order to stabilize $\mathrm{HCo}(\mathrm{CO})_{4}$ which might be present, this technqiue is too poor for restoring minute quantities of $\mathrm{HCo}(\mathrm{CO})_{4}$. It was found in the present work that $\mathrm{HCo}(\mathrm{CO})_{4}$ recombines immediately to $\mathrm{Co}_{2}(\mathrm{CO})_{8}$ when it passes a throttle valve so that $\mathrm{HCo}(\mathrm{CO})_{4}$ which might be present under the conditions in the reactor has already disppeared to a great extent on leaving the sample line at ambient pressure. Reliable information can thus be obtained only by performing the ir spectral analysis at conditions exactly identical with those of the hydroformylation experiment, as was done in the present work.

Secondly, the hydroformylation conditions reported by Markó (1963) and Orchin (1956) were different from those of the present work; both authors reported higher temperatures, pressure, and catalyst concentration. It is not unlikely that this affects the composition of the carbonyl species so that it deviates from that found in the present work. Recent work of Whyman (1974), who actually performed the ir analysis at in situ hydroformylation conditions, confirmed this: the "steady-state" spectrum consisted only of $\mathrm{Co}_{2}(\mathrm{CO})_{8}$ and the acyl complex and essentially no free $\mathrm{HCo}(\mathrm{CO})_{4}$ when octene-1 was hydroformylated at conditions in the range applied by Markó and Orchin. However, when an internal olefin rather than an $\alpha$-olefin was hydroformylated, the spectrum indicated free $\mathrm{HCo}(\mathrm{CO})_{4}$ besides $\mathrm{Co}_{2}(\mathrm{CO})_{8}$ and no acyl complex. So depending on the reaction conditions set, different steady-state patterns are exposed in the ir spectrum. Apparently free $\mathrm{HCo}(\mathrm{CO})_{4}$ is only present when hydroformylation rate is slow; the acyl complex appears only as a dominating species when the hydroformylation rate is fast. Since the hydroformylation is a gas-liquid reaction, serious limitations in the mass transfer of synthesis gas into the solution may occur when the chemical reaction, proceeding in the liquid phase, is very fast. An indication for the occurrence of this phenomenon can be found in the spectra of Whyman; the absorption peak of dissolved $\mathrm{CO}$ is much smaller when octene-1 is present than before the injection of octene. Also gas absorption measurements, which are reported in the following section of this paper, give a clear indication of a mass transfer limitation when the hydroformylation is performed at more severe conditions (temperature of $170^{\circ} \mathrm{C}, \mathrm{Co}_{2}(\mathrm{CO})_{8}$ concentration of approximately $45 \mathrm{mmol} / 1$.). A comparatively slow transfer from synthesis gas into the liquid affects especially the steady-state concentration of $\mathrm{HCo}(\mathrm{CO})_{4}$ which is formed from $\mathrm{Co}_{2}(\mathrm{CO})_{8}$ by hydrogen interaction, so each mole formed will be instaneously transformed into the acyl complex. The break-up rate of the latter is also dependent on $\mathrm{HCo}(\mathrm{CO})_{4}$ and is therefore also small. The steady-state ir spectrum will thus show a composite of the acyl complex and $\mathrm{Co}_{2}(\mathrm{CO})_{8}$ only.

As a tentative conclusion one may say that the rates of the individual intermediate reactions in the hydroformylation are affected in a different way by the reaction conditions set. The composition of the carbonyl species under hydroformylation conditions is thus dependent thereon and reflects itself in a changing ir spectral pattern.

2. Hydroformylation with the Cobalt Carbonyl-Tri- 


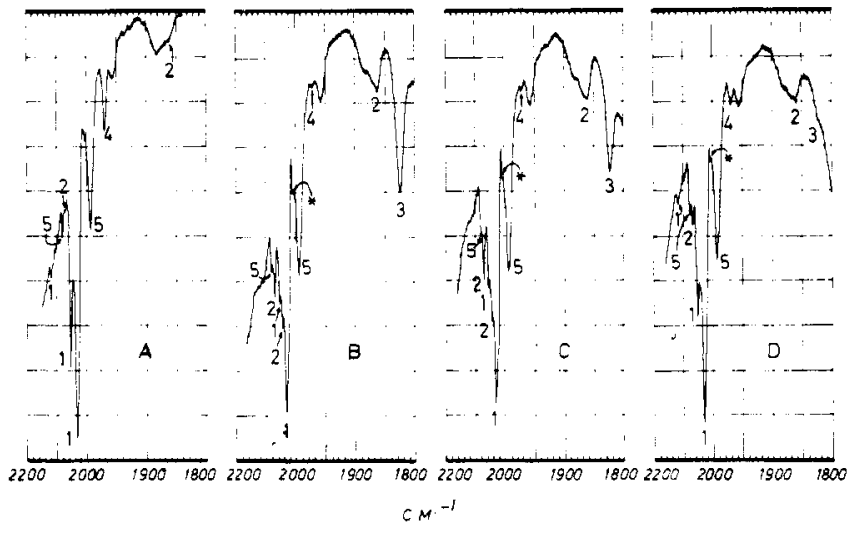

Figure 5. In situ ir spectra taken at different stages of the hydroformylation of octene-1 with cobalt carbonyl-tributylphosphine catalyst: $100^{\circ} \mathrm{C}, P_{\mathrm{CO}}=11$ bars, $P_{\mathrm{H}_{2}}=49$ bars, [cobalt] $=2.06$ $\mathrm{mmol} / \mathrm{l}$.; [tributylphosphine] $=10.5 \mathrm{mmol} / \mathrm{l}$; initial [octene] 0.325 $\mathrm{mol} / \mathrm{l}$. A, preformed catalyst; B, 6 min after octene injection; C, 38 min after octene injection; $D, 175$ min after octene injection; 1 , $\mathrm{HCo}(\mathrm{CO})_{4} ; 2, \mathrm{Co}_{2}(\mathrm{CO})_{8} ; 3$, octene- $1 ; 4, \mathrm{HCo}(\mathrm{CO})_{3} \mathrm{PBu}_{3} ; 5, \mathrm{Co}_{2}-$ (CO) ${ }_{7} \mathrm{PBu}_{3}$; *, acyl cobalt carbonyl (not liganded by $\mathrm{PBu}_{3}$ ).

butylphosphine Catalyst. It was found by Slaugh and Mullineaux (1968) and by Tucci (1968) that addition of $\mathrm{PBu}_{3}$ to cobalt carbonyl gave a profound improvement of the yield of unbranched products in the hydroformylation of propene, already at a P-to-Co ratio of 1 . Later, Rupilius et al. (1971) reported that this depended also on the catalyst concentration because lower cobalt concentrations yielded lower unbranched products. The authors explained this tentatively by the equilibrium $\mathrm{HCo}(\mathrm{CO})_{4}+\mathrm{PBu}_{3} \rightleftharpoons$ $\mathrm{HCo}(\mathrm{CO})_{3} \mathrm{PBu}_{3}+\mathrm{CO}$ being displaced more to the left with lower cobalt concentrations. In preliminary experiments we found no effect at all of $\mathrm{PBu}_{3}$ in the unbranched product yield, even at $\mathrm{P}$-to-Co ratios much higher than 1 , but at temperatures and cobalt carbonyl concentrations much below the values reported by Tucci (1968) of $160^{\circ} \mathrm{C}$ and approximately $50 \mathrm{mmol} / 1$. of $\mathrm{Co}_{2}(\mathrm{CO})_{8}$, respectively.

Attempting to obtain more detailed and direct information on the relation between the performance of the cobalt carbonyl-PBu$u_{3}$ catalyst and the reaction conditions, experiments were executed at $100^{\circ} \mathrm{C}$ with octene- 1 and $\mathrm{Co}_{2}(\mathrm{CO})_{8-}$ $\mathrm{PBu}_{3}$ in a P-to-Co ratio of 5:1. The catalyst composition at reaction conditions was recorded during the experiment by in situ ir spectroscopy.

A set of ir spectra, measured at proceeding stages of the hydroformylation reaction, is shown in Figure 5 . The change with the reaction time in the ratio of the different species, as calculated from the relative intensities at their characteristic frequencies, is illustrated in Figure 6a. It is clearly seen that, although $\mathrm{PBu}_{3}$ is present in excess, only a part of the carbonyl species is substituted by $\mathrm{PBu}_{3}$. $\mathrm{Co}_{2}(\mathrm{CO})_{8}$ is partly transformed into $\mathrm{Co}_{2}(\mathrm{CO})_{7} \mathrm{PBu}_{3}$ while $\mathrm{Co}_{2}(\mathrm{CO})_{6}\left(\mathrm{PBu}_{3}\right)_{2}$ is absent. The catalytically active species $\mathrm{HCo}(\mathrm{CO})_{4}$ is only for a minor part converted into $\mathrm{HCo}$ $(\mathrm{CO})_{3} \mathrm{PBu}_{3}$, so that profound changes in the reaction pattern are not likely.

This was indeed found from the GLC analysis, which indicated no change in the yield of unbranched products (77.6\%) nor an enhancement of the aldehyd hydrogenation (no alcohols were formed) compared with the results obtained in the absence of $\mathrm{PBu}_{3}$. The only difference found was a lower conversion rate of octene-1, which is most likely caused by the lower "steady-state" concentration of $\mathrm{HCo}(\mathrm{CO})_{4}$ (see Figures 3 and 6 ). The reactivity of $\mathrm{HCo}-$ (CO) ${ }_{3} \mathrm{PBu}_{3}$ is too low to compensate for this effect, which originates from the generally known fact that the activity

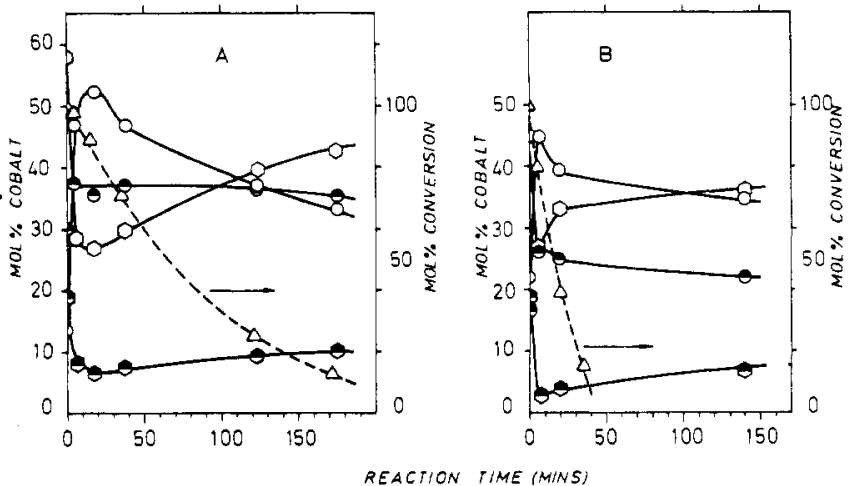

Figure 6. Cobalt carbonyl composition and octene-1 conversion as a function of reaction time: $\mathrm{O}, \mathrm{HCo}(\mathrm{CO})_{4} ; \mathrm{O}, \mathrm{Co}_{2}(\mathrm{CO})_{8} ; \bullet, \mathrm{HCo}$ $(\mathrm{CO})_{3} \mathrm{PBu}_{3} ; \bullet, \mathrm{Co}_{2}(\mathrm{CO})_{7} \mathrm{PBu} ; \quad \Delta$, octene-1. A. See legend Figure 5; yield of unbranched aldehydes formed: $78 \%$. B. $124^{\circ} \mathrm{C}, P_{\mathrm{CO}}=20$ bars, $P_{\mathrm{H}_{2}}=60$ bars, [cobalt] $=4.34 \mathrm{mmol} / \mathrm{l}$; [tributylphosphine] $=$ $20.85 \mathrm{mmol} / \mathrm{l}$; yield of unbranched aldehydes formed: $83 \%$.

of $\mathrm{HCo}(\mathrm{CO})_{3} \mathrm{PBu}_{3}$ is much lower than the activity of $\mathrm{HCo}(\mathrm{CO})_{4}$.

No vibrations characteristic for intermediate species other than the weak shoulder of the acyl complex, slightly above $2000 \mathrm{~cm}^{-1}$, can be recognized in Figure 5 . This agrees well with the cobalt balance calculated from the spectra in Figure 5, which does not leave more than a few percent of cobalt to be converted into octene-carbonyl complexes.

The experiment was repeated at a temperature of $124^{\circ} \mathrm{C}$ (further reaction conditions, see Figure 6b). From in situ ir spectral data Figure $6 \mathrm{~b}$ was constructed, which illustrates no significant change in the ratio of liganded-to-nonliganded carbonyl species. The overall octene conversion increased as did the yield of unbranched products (83\%). A comparison of said data with same found in the absence of $\mathrm{PBu}_{3}$ (see section 1) yielded only a slight difference in octene conversion and no difference in the yield of unbranched products.

One may conclude that the specific catalytic influence of the cobalt carbonyl species liganded with $\mathrm{PBu}_{3}$ is effective only when the hydroformylation reaction is carried out at conditions which are also thermodynamically favorable for the carbonyl-PBu 3 ligand exchange.

With regard to the hydroformylation results of Tucci (1968), Slaugh and Mullineaux (1968), and Rupilius et al. (1971), a temperature of far above $124^{\circ} \mathrm{C}$ must be set to form $\mathrm{HCo}(\mathrm{CO})_{3} \mathrm{PBu}_{3}$ in excess of all other species; thus the overall ligand exchange reaction $\mathrm{HCo}(\mathrm{CO})_{4}+\mathrm{PBu}_{3} \rightleftharpoons$ $\mathrm{HCo}(\mathrm{CO})_{3} \mathrm{PBu}_{3}+\mathrm{CO}$ is apparently endothermic to the right. This seems to be confirmed also by the single data point of Whyman (1972), who found by ir spectroscopy that $\mathrm{HCo}(\mathrm{CO})_{3} \mathrm{PBu}_{3}$ is the predominant compound at $190^{\circ} \mathrm{C}$. Apart from the temperature and catalyst concentration, the concentration of dissolved $\mathrm{CO}$ affects the amount of $\mathrm{PBu}_{3}$ liganded species. Without hydroformylation the concentration of dissolved $\mathrm{CO}$ is determined only by the CO partial pressure. With hydroformylation going on, the $\mathrm{CO}$ concentration of the solution is also dependent on the ratio of the chemical reaction rate in the solution to the rate of mass transfer of $\mathrm{CO}$ from the suppressed gas into the solution. In case the latter is slower than the former, the actual $\mathrm{CO}$ concentration will be lower than the saturation value and consequently affects positively the degree of $\mathrm{PBu}_{3}$ liganding.

In order to substantiate the above mechanism, the gas absorption rate of $\mathrm{CO}$ was measured both at $120^{\circ} \mathrm{C}, 2.23$ $\mathrm{mmol}$ of $\mathrm{Co}_{2}(\mathrm{CO})_{8} / 1, \mathrm{P}$-to-Co $=2, P_{\mathrm{CO}}=P_{\mathrm{H}_{2}}=32-35 \mathrm{~atm}$ and conditions typical for Tucci's work (1968), namely 
$161^{\circ} \mathrm{C}, 46.5 \mathrm{mmol}$ of $\mathrm{Co}_{2}(\mathrm{CO})_{8} /$., P-to-Co $=2.5, P_{\mathrm{CO}}=P_{\mathrm{H}_{2}}$ $=32-35 \mathrm{~atm}$. The absorption rates of synthesis gas were measured under carefully controlled gas-liquid interfacial area, thus operating the autoclave as a stirred (or Lewis) cell whereby only the solution was mixed without disturbing the interfacial area (for the theory of gas-liquid absorption combined with chemical reaction, see Danckwertz, 1970).

It was found that the enhancement factor $F$ was approximately 1 at $120^{\circ}$ and $2.23 \mathrm{mmol} / \mathrm{l}$. of carbonyl while a value of 17 was measured at $161^{\circ} \mathrm{C}$ and $46.5 \mathrm{mmol} / 1$. of carbonyl. An $F$ value of 1 indicates a very slow chemical reaction in the solution compared to the gas-liquid mass transfer rate. The $\mathrm{CO}$ concentration in the solution is thus equal, or almost equal, to the saturation value. This was confirmed by the ir analysis and further by the observation that the overall octene conversion rate was independent of the impeller speed over $1250 \mathrm{rpm}$. Thus under the prevailing conditions, the degree of $\mathrm{PBu}_{3}$ liganding is only determined by the thermodynamics of the carbonyl-PBu $\mathrm{P}_{3}$ system.

On the other hand, a value of 17 for $F$, found at $161^{\circ} \mathrm{C}$, indicates a different kinetic regime. The chemical reaction in the solution is so fast that synthesis gas transferred into the solution is consumed almost instantaneously so that the concentration of same in the bulk of the liquid is very low. Consequently, the equilibrium $\mathrm{HCo}(\mathrm{CO})_{4}+\mathrm{PBu}_{3}=$ $\mathrm{HCo}(\mathrm{CO})_{3} \mathrm{PBu}_{3}+\mathrm{CO}$ is displaced more to the right-hand side, and an almost complete conversion to $\mathrm{HCo}(\mathrm{CO})_{3} \mathrm{PBu}_{3}$ can be reached already at a P-to-Co ratio of 1 . At a P-to-Co ratio lower than 1 only a part of the $\mathrm{HCo}(\mathrm{CO})_{4}$ present can be converted to $\mathrm{HCo}(\mathrm{CO})_{3} \mathrm{PBu}_{3}$ and the catalyst would be composed of both species. However, $\mathrm{HCo}(\mathrm{CO})_{4}$ is much less stable than $\mathrm{HCo}(\mathrm{CO})_{3} \mathrm{PBu}_{3}$; it decomposes in a $\mathrm{CO}$ deficient environment, so that the total concentration of catalytically active hydrido carbonyl species is lowered. Thus, instead of a gradual decrease of the hydroformylation rate with a P-to-Co ratio increasing to 1 , one may expect an increase of the rate. Actually this was observed by Tucci (1968). Paulik (1972), in reviewing Tucci's data, already proposed a partial decomposition of the catalyst as a tentative explanation for Tucci's observations. The gas absorption kinetics provide extra evidence for Paulik's proposal.

\section{Acknowledgment}

The authors are indebted to J. M. Alberigs and H. Pleiter for the construction of the apparatus and assistance in experimentation. Professor E. Oltay is acknowledged for his initiatives which resulted in this investigation.

\section{Literature Cited}

Bor, G., Spectrochim. Acta, 19, 2065 (1963)

Dankwertz, P. V., "Gas-Liquid Reactions", Mc-Graw-Hill, London, 1970.

Heck, R. F., Breslow, D. S., J. Am. Chem. Soc., 82, 750 (1960).

Heck R. F., Breslow, D. S., J. Am. Chem. Soc., 83, 4023 (1961).

King, R. B., "Organometallic Synthesis", p 98, Academic Press, London, 1965.

Markó, L., Bor, G., Almázy, G., Szabó, P., Brennstoff Chem., 44, 18 (1963).

Oltay, E., Penninger, J. M. L., Alemdaroglu, N., Alberigs, J. M., Anal. Chem., 45, $802(1973)$

Orchin, M., Kirch, L., Goldfarb, I. G., J. Am. Chem. Soc., 78, 5450 (1956).

Orchin, M., Rupllius, W., Catal. Rev., 6 (1), 85 (1972)

Paulik, F. E., Catal. Rev., 6 (1), 49 (1972).

Piacenti, F., Bianchi, M., Benedetti, E., Chim. Ind. (Milan), 49, 245 (1967).

Pregaglia, G. F., Andreetta, A., Ferrari, G. F., Ugo, R., J. Organomet. Chem. 30, 387 (1971).

Rupilius, W., McCoy, J. J., Orchin, M., Ind. Eng. Chem., Prod. Res. Dev., 10, 142 (1971).

Schwartzenbach, G., Flaschka, H., "Complexometric Titrations", p 241 Methuen, London, 1969

Slaugh, L. H., Mullineaux, R. D., J. Organometal. Chem., 13, 469 (1968)

Szabó, P., Markó, L., Bor, G., Chem. Technol., 13, 549 (1961).

Tucci, E. R Ind Eng. Chem Prod Res Dev, $7,32-(1968)$

Ungvary, F., J. Organomet. Chem., 36, 363 (1972).

Whyman, R., "Proceedings of the Symposium on Hydroformylation and Related Reactions", p 24, Vezprém, Hungary, 1972.

Whyman, R., J. Organomet. Chem., 66, C23 (1974).

Received for review August 12, 1974 Accepted June 25, 1975

\title{
Catalytic Reduction of Sulfur Dioxide with Carbon Monoxide on Cobalt Oxides
}

\author{
Joe G. I. Bazes, L. S. Caretto, and Ken Nobe* \\ School of Engineering and Applied Science, University of California, Los Angeles, Callfornia 90024
}

\begin{abstract}
The reduction of $\mathrm{SO}_{2}$ with $\mathrm{CO}$ on $\mathrm{LaCoO}_{3}, \mathrm{CeO}_{2}-\mathrm{CO}_{3} \mathrm{O}_{4}$, and $\mathrm{CuCo}_{2} \mathrm{O}_{4}$ catalysts has been investigated in the temperature range $284-465^{\circ} \mathrm{C}$, initial $\mathrm{SO}_{2}$ concentrations between 700 and $1400 \mathrm{ppm}$, and CO concentrations between 1 and 3 times the stoichiometric amount for complete reduction. Ninety percent reduction of $\mathrm{SO}_{2}$ or greater was obtained for temperatures above $380^{\circ} \mathrm{C}$ and CO concentrations of $2 \frac{1}{2}$ times the stoichiometric value. However, substantial COS was produced at high temperatures and large excess of $\mathrm{CO}$. On the other hand, carbon disulfide was not detected. Formation of $\mathrm{COS}$ was lessened by decreasing $\mathrm{CO}$ to $\mathrm{SO}_{2}$ initial concentrations to the stoichiometric ratio. The catalytic activity of $\mathrm{CeO}_{2}-\mathrm{Co}_{3} \mathrm{O}_{4}$ was greater than that of $\mathrm{CuCO}_{2} \mathrm{O}_{4}$ or $\mathrm{LaCOO}_{3}$. The experimental data were correlated with a power law rate equation and an analysis scheme to account for pore diffusion effects.
\end{abstract}

There has been recent interest in catalytic processes for reducing the sulfur dioxide in power plant stack gases with carbon monoxide. Ryason and Harkins (1967) found that copper-alumina and silver-alumina catalysts were effective for the simultaneous removal of both $\mathrm{SO}_{2}$ and $\mathrm{NO}$ from stack gases. They reported that formation of $\mathrm{COS}$ can be minimized by maintaining the mole ratio of $\mathrm{CO}$ to $\mathrm{SO}_{2}$ to slightly less than 2 (i.e., slightly less than the stoichiometric ratio for the complete reduction of $\mathrm{SO}_{2}$ to sulfur). Khalafalla et al. (1971) observed synergism of iron-alumina catalysts for the $\mathrm{SO}_{2}-\mathrm{CO}$ reaction. More recently, Querido and Short (1973) and Quinlan et al. (1973) studied the reduc- 